\title{
Bronisław Aleksander Jachimowski (1894-1937), oficer artylerii, działacz PCK
}

Bronisław A. Jachimowski, syn Juliana i Heleny z domu Kobylańskiej, urodził się 18 sierpnia 1894 r. w Kazimierzy Małej (pow. Pinczów). Po ukończeniu szkoły powszechnej kontynuował naukę w ośmioklasowym gimnazjum filologicznym w Warszawie, ale maturę uzyskał w dalekiej Kałudze, w roku 1916. 7 lipca tego roku zgłosił się do armii rosyjskiej i w stopniu kanoniera został skierowany do 76. Brygady Artylerii. Dosłużył się stopnia kaprala. Rok później był działonowym w Brygadzie Zapasowej I Korpusu Polskiego. 1 września awansował do stopnia chorążego. 22 stycznia 1918 r. dostał się do niewoli bolszewickiej, a następnie trafił do niewoli niemieckiej. Po zawarciu traktatu brzeskiego uwolniony i skierowany do Sztabu Twierdzy Bobrujsk na stanowisko oficera demobilizacyjnego, a 1 listopada 1918 r. zdemobilizowany.

Zgłosił się do Wojska Polskiego. 18 stycznia 1919 r., w stopniu podporucznika (ze starszeństwem od 1 października 1914 r.), został słuchaczem Szkoły Artylerii w Rembertowie. Po jej ukończeniu 15 marca otrzymał przydział do 9. Baterii III Dywizjonu 1. Pułku Artylerii Polowej Wielkopolskiej, a 12 kwietnia został dowódcą 4. Baterii II Dywizjonu. 15 lutego 1920 r. wyruszył wraz z pułkiem na front. Wziął udział w walkach na froncie ukraińskim - w ofensywie kijowskiej. 25 kwietnia odznaczył się w bitwie pod Cudnowem, za co został odznaczony Krzyżem Walecznych. 26 maja przeniesiono go do 8. Baterii II Dywizjonu. 23 czerwca powrócił z wojny i 21 lipca objął stanowisko 


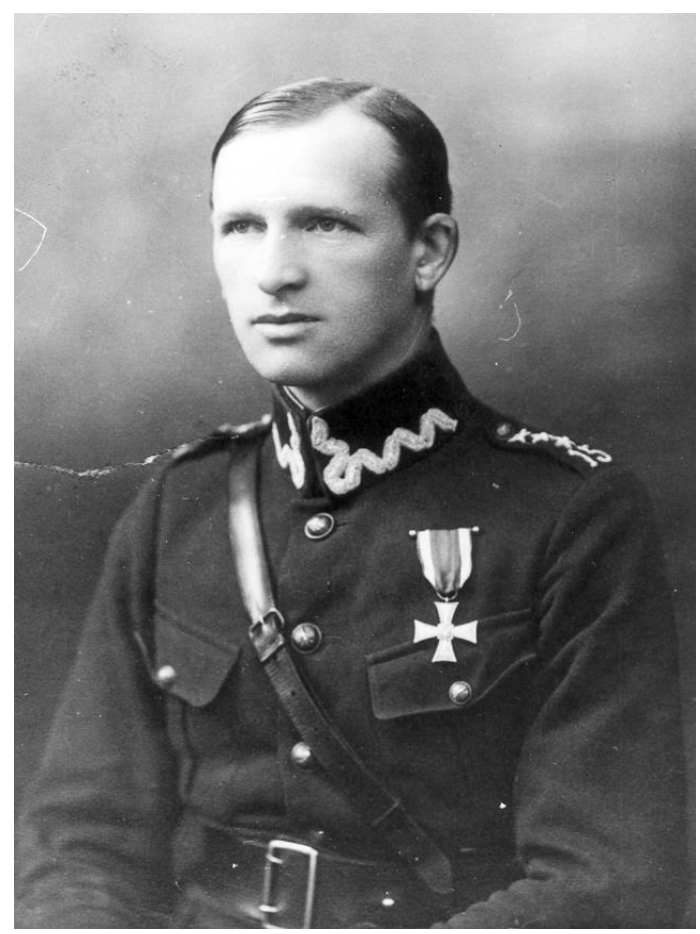

dowódcy Baterii Zapasowej 15. Pułku Artylerii Polowej. W okresie 17 października - 3 grudnia był uczestnikiem kursu Centrum Wyszkolenia Artylerii w Poznaniu, następnie powrócił do pułku i 11 stycznia 1921 r. został starszym oficerem 2. Batalionu, a 28 lutego otrzymał awans na stopień porucznika (ze starszeństwem od 1 kwietnia 1920 r.). 13 lipca został oficerem broni pułku. 8 maja 1922 r., w stopniu kapitana, objął stanowisko adiutanta dowódcy pułku. Mimo kłopotów ze zdrowiem (choroba nerek) wzorowo wywiązywał się z obowiązków i otrzymywał wiele pochwał. 7 grudnia 1923 r. skierowano go na dowódcę 8. Batalionu 15. Pułku Artylerii Polowej, który wówczas stacjonował w Bydgoszczy. W terminie 1 kwietnia - 2 października 1925 r. ukończył kurs dowódców baterii w Szkole Strzelania Artylerii, a następnie został dowódcą 1. Batalionu 15. Pułku Artylerii Polowej. Od 5 kwiet- 
nia 1927 r. był oficerem dla spraw materiałowych i kwatermistrzem w Szkole Podoficerów Zawodowych Artylerii, w roku 1929 adiutantem dowódcy, w 1930 instruktorem, a od 19 lipca tego roku dowódcą baterii szkolnej. 27 lutego $1932 \mathrm{r}$. awansował do stopnia majora.

28 lutego 1932 r. został przeniesiony do 8. Pułku Artylerii Ciężkiej w Toruniu na stanowisko dowódcy I Dywizjonu. Od 20 września do 8 listopada 1933 r. był słuchaczem toruńskiej Szkoły Podchorążych Artylerii. W dniach 12-25 czerwca 1935 r. był członkiem Komisji I Próby o Państwową Odznakę Sportową przy 8. Pułku Artylerii Ciężkiej. Ponieważ nasilały się kłopoty ze zdrowiem, co niekorzystnie odbijało się na przebiegu służby, 17 lipca 1935 r. został oddany do dyspozycji dowódcy DOK VIII, a 31 października tego roku przeniesiony w stan spoczynku.

Od połowy lat trzydziestych był związany z PCK. Z ramienia Okręgu Pomorskiego kierował stacją ratownictwa rzecznego na Wiśle, ale udzielał się też w pracy Kół Młodzieży, m.in. 13 maja 1936 r. przewodniczył Zjazdowi Kół w Tucholi.

Zmarł tragicznie 13 maja 1937 r. w Toruniu.

Za zasługi wojenne był odznaczony: Krzyżem Walecznych (9 VI 1925), Medalem Pamiątkowym za Wojnę 1918-1921 (1928), Medalem Dziesięciolecia Odzyskania Niepodległości (1928), Państwową Odznaką Sportową kl. II/3 st. (3 X 1935) i francuskim Medalem Zwycięstwa „Interalliée de la Victoire” (1925).

Źródła: Centralne Archiwum Wojskowe, teczki: Ap 2114 i KW 41/J-100; Archiwum Państwowe w Toruniu, zesp. AmT, D IV, sygn. 5946; Sprawozdanie Okręgu Pomorskiego P.C.K. za rok 1936, Toruń 1937; L. J. Welker To już tyle lat, Toruń 2000. 